\title{
The Ideological Content of Tuvan Folklore and the Elements of Freethinking
}

\author{
Olga M. Khomushku* and Zoia K. Kyrgys \\ Tuvan State University \\ 36 Lenin Str., Kyzyl, Republic Tuva, 667000, Russia
}

Received 15.09.2018, received in revised form 26.11.2018, accepted 10.12.2018

The issues of the ideological content of Tuvan folklore and its components and moments which also include elements of freethinking are analyzed and explored in this article. The analysis of the nature of both religious views and beliefs, as well as anti-clerical and anti-church views, which were reflected in Tuvan folklore, is of great importance in this research.

Keywords: National folklore, freethinking (freedom of thought), Upper world, Middle world, Lower world, worldview, mentality, type of thinking, Buddhism, shamanism.

Research area: culturology.

Citation: Khomushku, O.M., Kyrgys, Z.K. (2018). The ideological content of Tuvan folklore and the elements of freethinking. J. Sib. Fed. Univ. Humanit. soc. sci., 11(12), 1962-1967. DOI: $10.17516 / 1997-1370-0369$.

Traditional mythological thinking shaped and sanctified Tuvan norms of behavior, life goals, lifestyle, preferences and aspirations. There was no fundamental difference between a human and the nature for Tuvans. Not only the fear, but the importance of the natural processes determined anthropologization (humanization) of nature. Tuvan people imagined the world as a human-nature unity permeated by the higher, mysterious forces.

According to the archaeological evidence, even in the ancient times there was a fairly well-developed religious worldview for Tuvans which contained the layers of ecosophic and cosmogonic ideas and was reflected in Tuvan beliefs, rituals and religious symbols. Ethnocultural traditions of the peoples of the region were formed as a result of close interaction of the natural landscape, autochthonous beliefs and, later, powerful influence of Buddhism. The specific way of life, due to the geographical conditions, had an impact on the originality of the religious beliefs which were formed

(c) Siberian Federal University. All rights reserved

* Corresponding author E-mail address: hom17@mail.ru

This work is licensed under a Creative Commons Attribution-NonCommercial 4.0 International License (CC BY-NC 4.0). 
in the territory of Tuva. In this case, the spiritual world exploration in the human world was perceived through dualism - this-worldly and other-worldly world (nevertheless, this duality was conflict-free, i.e. quite harmonious).

Tuvans had quite a coherent system of cosmogonic myths which explained the origin of the world and man; the characteristic feature of the system was the idea of the harmony in the world, the involvement of the person in this world, the integrity of this world with its multidimensionality and diversity. The plots of myths tell (in different versions) about the creation of the world in some detail, about its division into three-level structure: the Upper world - the Middle world - the Lower world. In Tuvan mythology there is a division into two principles - Heaven (masculine) and Earth (feminine) (compare with Chinese Yin and Yang). By the way, other peoples of the Altai-Sayan mountains have similar stories.

The moments of life in which people act as an active creative force have a predominant influence on the minds of every nation: labor, mutual assistance in labor and hardships, unity to fight back the enemy, etc. These aspects of people's life appear as a force affirming the value of human existence. Despite all the difficulties and hardships experienced by people in ancient times, they aroused in their minds the desire to look for natural causes of the phenomena of the surrounding world to influence them and change the course of events in the desirable for a person order.

Folklore had a special significance and meaning for the Tuvan people. For a long time, it remained the only means for people to express their thoughts and aspirations, their moods and dreams. In spoken compositions, the Tuvan people reacted to almost all the life and historical events.

Having originated in the ancient times and having overcome all the twists and turns of history, Tuvan folklore passed from generation to generation and has reached the present time. At the same time, every next generation contributed something of its own to the wealth which was inherited from the previous generation and renewed the thoughts, the ideas and the culture of ancestors in accordance with the new experience of work and social life.

One of the features of Tuvan folklore (as well as many other peoples) was the presence of religious skepticism, often bordering on freethinking. These are the origins of human freethought, skepticism and anti-clericalism, which sometimes lead to obviously atheistic ideas. This feature of the folk worldview is manifested in the folklore. It synthesizes realistic and romantic exploration of reality, rich empirical experience, folk wisdom and rational knowledge. 
Being rich in genres and types, the Tuvan folklore was, in fact, a reflection of socioeconomic relations in Tuva and the worldview of the people. Anti-Church sentiments and social protest were directly reflected in the spoken folklore. Anti-Church ideas can be traced in Tuvan proverbs and sayings most clearly. In the proverbs, it is easy to see outright hostility and even contempt of simple Tuvan people for the clergy (lamas, shamans), condemning lamas and shamans for their greed and avarice. For example, "If there are a lot of khuuraks, the people become poorer. If there are a lot of foals born, the people get richer" (In Tuvan khuuraks are lamas or Tuvan priests) ("Хуурактар ковудээрге, ядараарынын демдээ, кулун, чаваа ковудээрге, байыырынын демдээ"), or "In search of cattle, arat climbs the hills, in search of the gifts, lama hangs about the yurts" (arat is an ordinary person) (“Мал дилээнде - бедие унер, падарлаанда - оглер кезиир"), or "There is little use for the field from tumbleweed, we see less good from a wandering priest” (“Кашпык-уурге чуктээн бадарчыдан, хатка чуулган канн мыыл дээре"). Such well-aimed expressions speak of the moral evaluation of priests by the Tuvan people "If the stomach is full, it is possible to live without honor" (“Хырны мурнаан, ады соннаан”), or “A dog is getting fatter from a jute, lamas are becoming richer from a disease” (“Чут болурга ыыт семириир, аарыг болурга лама байыыр”), “Where the lama passes - misfortune is always there, wherever he comes, there is always trouble" (“Чораан черинге шончактыг, барган черинге балалыг”) (Tuvan proverbs, 1972).

Thus, anti-clericalism was the most typical manifestation of the anti-religious tendency in the national consciousness connected with the social protest, and initially, people's anti-clericalism was expressed in condemnation of certain traits of priests of the cult (self-interest, avariciousness, hypocrisy in the matters of faith, etc.).

Reflecting in proverbs and sayings their ideological attitudes, the people made certain conclusions: "The thunderstorm is not terrible - and the prayer is not necessary” (“Булуттан кортпа, бурганга тейлеве”), or "Without God, the road is open” (“Бурганччокта орук ажык”) (Tuvan proverbs, 1972).

There were also many anti-Church fairy-tales among the Tuvan people. Greedy lamas and shamans were derided; people condemned their parasitism in fairy-tales, as well as in proverbs and sayings. As a rule, lamas and shamans seem to be avaricious, greedy, and often stupid people in these tales. They are opposed to the representatives of the people or the animal world which become winners in all conflicts with the clergy.

In the tale "The Grey Hare" (Tuvan folk tales, 1972) the initial episode tells us how the hare outwitted a wandering lama. "Once upon the time, there lived a grey hare in 
a dense forest. One day the grey hare ran out of the forest and saw a lama on the road. He carried a box of sacred books on his back. The grey hare pretended to be lame and lay down on the road. When the lama approached him, the gray hare jumped up, as if he was frightened, and ran limping. "I will kill the lame hare" thought the Lama, he put down the box and started pursuing the hare. To make it easier to run, at first the lama took his gown off, then shoes, but it did not help. Then he took off everything he was wearing. The lame hare jumped faster and faster and jumped into the forest. So, the lama could not catch the grey hare. "What a rascal! The hare outsmarted even me", he cursed the hare.

In the fairy tale "Badarchy Lama" (2), a stupid wandering lama, who could not decide what direction it is better to go - to the left or to the right, was an object of derision. "If I go to the right, the left road will be mad at me. If I go to the left, the right road will get angry. What should I do?" The lama thought about it and decided to walk two roads at once - one foot on the right road, and another one on the left road. A ground squirrel looked out from its burrow and beeped: "You have so many sins, Yellow Cap, it is impossible for you to walk two roads at the same time." The lama became angry, but continued to walk, placing his feet wider and wider. So, stubborn Lama kept walking until he cracked in half.

The fairy tale "Porridge in the Pot" tells the story of greed. There was a lama wandering outside in the evening in winter. He was carrying an old bag of prayer books. The lama was looking at yurts, with smoke from the hearth, and sniffed, where it smelt tastier. The lama went into one of the yurts, where they cooked millet porridge, but decided that it was too salty, so he asked for a little bit of it. But the millet porridge was very tasty. At night, when everybody was asleep, the hungry lama grabbed the pot with the porridge, but he could not get it out from the pot because his clenched fist could not get through the narrow spout. He tried to break the pot against the stone, but the stone turned out to be a dog, he tried to break the pot on a hill, but it was a camel. He hit the pot against the post at the sheep stable, but he woke the shepherds, they decided that it was a thief and rushed to the lama. He started running without looking back, choked on a quick run and fell dead.

Thus, according to the given episodes from the Tuvan national fairy tales it is possible to say that not all the representatives of clergy were respected by the ordinary population. Moreover, in fairy tales it is possible find the episodes which describe ordinary people as smarter and more efficient than lamas. So, the tale "The old Man Adyga" tells the story about the nine sons of the old man Adygan, how they found 
Karaty-Khan's youngest daughter with the help of their minds and skills while lamas and shamans failed to do it. A lama and a shaman were invited. After the big ritual, the shaman said: "Maybe we can find your daughter, just the right rich offerings are needed." The Lama looked at the prayer book and said: "Maybe your daughter will be found, if you bring great gifts..." An old man came up: "The Shaman and the Lama will not help. Your daughter will be found only by the sons of old Adygan" (Tuvan folk tales, 1972).

The results of practical learning of the world are embodied in the folklore in general and in fairy tales in particular. At the same time, in fairy tales the reflection of the objective reality is not a mirror copy but a dead imprint of certain realities. Recreating the pictures of people's life, the fairy tale harmoniously combines reality and fiction, fantasy and sobriety of mind. The specific features of the genre helped to combine the past and the future of folk beliefs and ideals in one view.

The creators of fairy tales reflected not only objects, but themselves as well; they not only taught the younger generation, but also studied themselves. This showed the effectiveness of the naive-materialistic foundation of the people's worldview, which was strengthened and developed in the process of versatile historical practice.

Creating artistic images of characters in fairy tales, the people used ancient fantastic ideas of a man about his own and the surrounding nature, but changing and processing these ideas in a certain way. Therefore, the general spirit of struggle, which was characteristic, for example, of heroic tales, does not lead to the deification of the forces of nature, but generates a belief in the possibility of man's victory over them. So, in the fairy tale "The Old Man and the Evil Spirit of Mangys" (Tuvan folk tales, 1972), despite the fantastic events are described, the main thing is not a supernatural origin, but the mind and resourcefulness of the old man who outwitted the evil spirit. The tale "The Boy and the Witch" has a similar meaning, telling about how Baldyr-bezhic (Tiny boy) outsmarted Chylbyga (the witch) who wanted to eat him.

These fairy tales gave a spoken account of life-affirming faith in the capabilities of a person, in his/her abilities to overcome all the dark forces. The elements of nonreligious worldview were reflected in the folk art in this way.

However, we should not forget that along with the anti-religious sentiments the fairy tales reflected the wishes and desires of the Tuvan people, which were linked to their hopes for the aid of the gods, the lords of the Lower world and the Upper world (Erlik Khan and Curbustu Khan) in the solution of many problems. There were two origins in the people's the worldview: on the one hand, religious, and on the other hand, 
naive and materialistic ideas. The former were caused by the natural forces, in which the dominance of nature over people was manifested, and the latter were caused by the impact of a person on social reality and nature.

Both fairy tales and religion originated initially as the forms of reflection of the unconscious powerlessness of man in the face of nature. Ancient people did not know the profound laws of nature, and this led to the general relativization of things and to arbitrary linking them with each other. Each thing was perceived by them not only as a set of its natural features, but also as something mysterious and supernatural.

According to L.V. Grebnev, "...in the recent past, the worldview of the Tuvan people was permeated with the influence of shamanism and lamaism. Both epos and shamanic performance existed among the same people at the same time. The ritual of the shaman, the prayers of the lama and the performance of the epic work could not happen in one yurt at the same time. In both cases the people heard about supernatural forces of omnipotent gods" (Grebnev, 1980).

\title{
References
}

Tuvan proverbs and sayings. (1972). Kyzyl.

Tuvan folk tales. (1972). Kyzyl.

Grebnev, L.V. (1980). Tuva Heroic Epos (Experience of Historical and Ethnographic Analysis), M.

\section{Идеологическое содержание тувинского фольклора и элементы свободомыслия}

\author{
О.М. Хомушку, 3.К. Кыргыс \\ Тувинский государственный университет \\ Россия, 667000, Республика Тььва, Кьзылл, ул. Ленина, 36
}

В статье анализируются вопросы мировоззренческого содержания народного фольклора тувинцев, исследуются его составные части и элементы, включающие и элементы свободомыслия. Важное значение в системе исследования приобретает анализ характера проявления как религиозных взглядов и представлений, так и антиклерикальных и антицерковных воззрений, нашедших свое отражение в тувинском фольклоре.

Ключевые слова: народный фольклор, свободомыслие, Верхний мир, Средний мир, Нижний мир, мировоззрение, ментальность, буддизм, иаманизм.

Научная специальность: 24.00.00 - культурология. 